\title{
Predation of the hooded skunk, Mephitis macroura, by the great horned owl, Bubo virginianus, in the Barranca de Metztitlán Biosphere Reserve, Hidalgo, México
}

\section{Depredación del búho cornudo (Bubo virginianus) sobre el zorrillo listado (Mephitis macroura) en la Reserva de la Biosfera Barranca de Metztitlán, Hidalgo, México}

\author{
Gerardo Sánchez-Rojas ${ }^{1 *}$, Zeltzin K. Zepeda-Hernández ${ }^{1}$, Juan A. Hernández-Melo ${ }^{1}$, Carlos A. Maciel-Mata ${ }^{1}$, and Dante A. Hernández-Silva ${ }^{1}$ \\ 'Universidad Autónoma del Estado de Hidalgo, Instituto de Ciencias Básicas e Ingeniería, Centro de Investigaciones Biológi- \\ cas, Laboratorio de Conservación. Ciudad del Conocimiento km 4.5 de la Carretera Pachuca-Tulancingo s/n, C. P. 42186. Mi- \\ neral de la Reforma, Hidalgo. E-mail: gsanchez@uaeh.edu.mx (GS-R); zeltzin.zepeda.deuterostomados@gmail.com (ZKZ-H); \\ forest.hernandezmelo6@gmail.com (JAH-M); camacielmata@gmail.com (CAM-M); dal silva@hotmail.com (DAH-S). \\ *Corresponding author
}

Documenting and describing natural history events such as predation contribute to better understand the ecological responses of species. This note describes the predation of a hooded skunk individual, Mephitis macroura, by the great horned owl, Bubo virginianus, based on video recording and photographs. Audiovisual materials were obtained as part of the camera-trap sampling of carnivorous mammals in the Barranca de Metztitlán Reserve during August-December 2016. Camera traps record the time and date of events, thus allowing an accurate recording of the interactions between the owl and the skunk individuals. Three photographs and two 10-second videos were examined. One of the videos recorded the skunk vocalization upon being attacked by the owl. The entire second video shows the inert skunk. The two species could be accurately identified on the photographs. Skunks display an aposematic coloration that is usually a highly effective camouflage to hide from terrestrial predators. However, this seems to be ineffective against nocturnal birds of prey. Owls are probably the main regulators of skunk populations. This record shows that such interaction is maintained even at the southernmost end of the distribution range of the two species.

Key words: Camera traps; monitoring; natural history; photo interpretation; predation.

Documentar y describir los eventos de historia natural como la depredación son de gran ayuda para entender las respuestas ecológicas de las especies. En esta nota se describe la depredación del búho cornudo (Bubo virginianus) sobre un zorrillo listado (Mephitis macroura) mediante la descripción de un video y una serie de fotografías. El material audiovisual se obtuvo durante un muestreo enfocado en mamíferos carnívoros usando trampas cámara durante los meses de agosto a diciembre de 2016, en la Reserva Barranca de Metztitlán. El material registra la hora y el día de los eventos por lo que se pudo registrar la interacción entre el búho y el zorrillo. Se obtuvieron tres fotografías y dos videos de 10 segundos, en uno de ellos se registró la vocalización del zorrillo cuando es atacado por el búho. El segundo video se mantiene con la misma imagen del zorrillo abatido. En las fotografías es posible distinguir sin duda la identidad de ambas especies. Los zorrillos son una especie con una coloración aposemática que suele ser muy efectiva para camuflajearse de depredadores terrestres. Sin embargo, en el caso de las rapaces nocturnas, ésta parece ser inefectiva y probablemente los búhos sean los principales reguladores de las poblaciones de zorrillos. Este registro implica que esta interacción se mantiene aún en las regiones más sureñas de la distribución de ambas especies.

Palabras clave: Depredación; fotointerpretación; historia natural; monitoreo; trampas cámara.

@ 2021 Asociación Mexicana de Mastozoología, www.mastozoologiamexicana.org

Interactions between vertebrate species in the wild cannot always be observed or recorded directly. The increasing use of camera traps has contributed to significantly expand the monitoring and study of terrestrial mammals in recent years (Mandujano 2019). As a result, numerous observations on the natural history of mammals and other species have been made possible. Photographs recorded during camera-trapping studies often allow observing the behavior of and interactions between species and, in addition to confirming their occurrence, these document their temporality as data on the date, time, and some environmental aspects are also recorded (Jenkins et al. 2011; Norouzzadeh et al. 2018).
Predation is one of the interactions that has been recorded in camera-trap materials as videos or photographs often allow clearly identifying the interacting species. For example, a jaguar directly predating on a crocodile (Simá-Pantí et al. 2020), or the likely association between species to reduce the risk of predation, as documented for the southern spotted skunk, Spilogale angustifrons, which subordinates its movements to those of the gray fox, Urocyon cinereoargenteus, in arid (FaríasGonzález and Vega-Flores 2019) and warm subhumid (Mejenes-López et al. 2021) environments. Photographic records are often the only evidence available on rare events, such as the predation by a carnivore. 
This note describes a predation event of a hooded skunk individual, Mephitis macroura, by the great horned owl, Bubo virginianus, based on the examination of a video recording and photographs captured during a study of carnivorous mammals in the Barranca de Metztitlán Biosphere Reserve, state of Hidalgo, in 2016.

The event was documented during a field study using camera traps to record carnivorous mammals. The monitoring was carried out from August to December 2016 within the boundaries of the Barranca de Metztitlán Biosphere Reserve. The reserve was decreed by the Mexican government in March 2000 and registered by UNESCO in October 2006. The reserve is in the state of Hidalgo, México $\left(20^{\circ} 14^{\prime}\right.$ $15^{\prime \prime}-20^{\circ} 45^{\prime} 26^{\prime \prime} \mathrm{N}, 98^{\circ} 23^{\prime} 00^{\prime \prime}-98^{\circ} 57^{\prime} 08^{\prime \prime} \mathrm{W}$ ) and comprises a total area of 96,042.94 ha (CONANP 2003).

The reserve is characterized by a rugged topography with steep slopes; the elevation ranges from 1,000 to 2,000 $\mathrm{m}$. The local climate is dry, semi-warm with a summer rainy season (García 1973); the mean annual temperature varies between 18 and $22{ }^{\circ} \mathrm{C}$, and the mean annual precipitation is less than $600 \mathrm{~mm}$. The reserve harbors eleven vegetation and six land-use types. Crassicaulescent shrubland is the most extensive vegetation type $(19.18 \%$ of the total area of the reserve), followed by pine forest (15.83\%), submontane shrubland $(10.53 \%)$, oak forest $(10.43 \%)$, and other vegetation types (11.93\%); the rest of the reserve (32.1\%) is covered by irrigated and rain-fed agriculture, urban zones, induced or cultivated pastures, and areas with no vegetation (INEGI 2016).

A total of 30 photo-trapping stations were set for the sampling; in each station, a Cuddeback E2 long range IR, $20 \mathrm{MP}$-resolution camera was fitted. Stations were located within the reserve following two criteria: vegetation type and easy of access along existing trails, aiming to sample the full extent of the reserve and keeping a minimum distance of $1.5 \mathrm{~km}$ between adjacent camera traps.

The sampling was carried out for 150 days for a total sampling effort of 4,500 camera-days. In this period, hooded skunk individuals were recorded in 13 capture events, while the great horned owl was only recorded in another locality. The predation event took place on 17 December 2016 and was recorded by a camera trap located in the El Palmar town, municipality of Metztitlán ( $20^{\circ} 30^{\prime} 33^{\prime \prime} \mathrm{N}, 98^{\circ} 48^{\prime}$ $\left.54^{\prime \prime} \mathrm{W}\right)$; four photographs and two 10-second videos were recorded. The video recordings can be viewed at the following links: https://youtu.be/LMoj-S-uQRQ and https:// youtu.be/DWGxDUdjTLk.

Figure 1 shows the chronological sequence of the recorded predation event of a hooded skunk by a great horned owl. a) A photograph captured at 7:43 pm shows, to the lower right, the wing of a horned owl and the tail of a hooded skunk. b) A frame from a video shows the head of the owl, which confirms its identity. c) A photograph captured seven minutes later (7:50 pm) shows the owl fly-

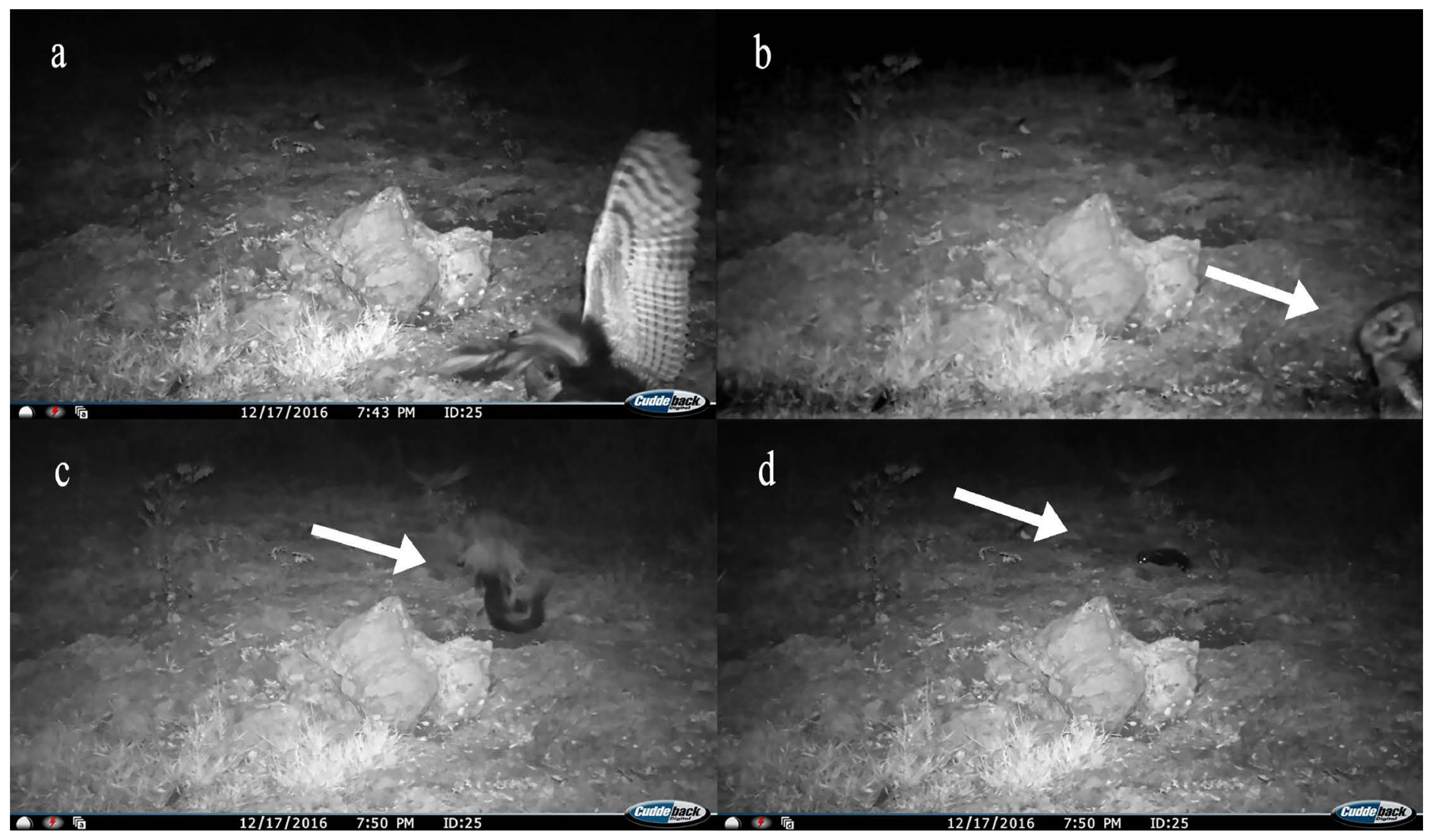

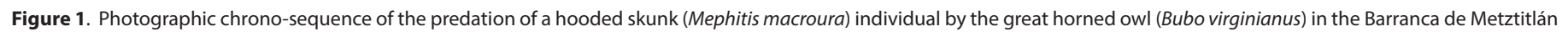

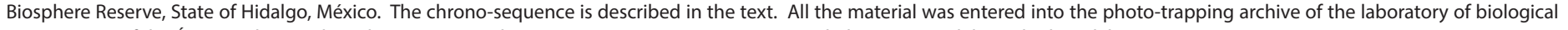
conservation of the Área Académica de Biología, Instituto de Ciencia Básica e Ingeniería, Universidad Autónoma del Estado de Hidalgo. 
ing and carrying the hooded skunk in its claws; the tail and the back of the owl and the tail of the skunk under the owl are clearly seen, which confirms the identity of the two species. d) This photograph shows the hooded skunk lying some 6 meters away from the camera trap; its bright eyes stand out, and it can be assumed that it was already dead. A video was recorded immediately after the latter photograph; this shows the same image for the entire 10-second length. This camera was reviewed again 10 days after the event, but no trace of the skunk could be found around, and no further events were recorded. All the audiovisual materials recorded were entered into the photo-trapping archive of the Laboratory of Biological Conservation of the Department of Biology of the Institute of Basic Science and Engineering (Área Académica de Biología, Instituto de Ciencia Básica e Ingeniería) at Universidad Autónoma del Estado de Hidalgo.

Hooded skunks are nocturnal carnivores whose anal glands produce toxic chemical secretions that they can spray out when faced with a potential predator threat. All skunks have black-and-white colored coats; this is the aposematic color signal most commonly found in mammals and acts as a warning for predators. These defense mechanisms are likely successful for evading terrestrial predators in the open environments where skunks are more susceptible to being attacked (Stankowich et al. 2014). However, they do not seem to be highly effective against nocturnal aerial predators such as owls; in fact, predation by owls has been identified as the main cause of mortality for some skunk species of the genera Spilogale (Lesmeister et al. 2010), Conepatus (Anza and Zilio 2015), and Mephitis (Fisher and Stankowich 2018).

It is also likely that owls feed on skunks more frequently than what has been reported in feeding studies. Such studies are usually based on the analysis of pellets in which regularly eaten, small and medium-sized prey, mainly lagomorphs and rodents, are more easily observed (Zimmerman et al. 1996; Tomazzoni et al. 2004; Kopij 2016). Remains of carnivores such as weasels (Mustela frenata; Kremer and Belk 2003) are hardly detected in pellets. Thus, the role that the great horned owl plays in the regulation of populations of this type of carnivores might be underestimated (Tomazzoni et al. 2004; Lesmeister et al. 2010; Anza and Zilio 2015).

Recording this type of events is important, as these may document the role of the great horned owl in regulating hooded skunk populations. Our record may also be related to unconventional interactions such as the one observed between the gray fox and the spotted skunk (FaríasGonzález and Vega-Flores 2019; Mejenes-López et al. 2021). Camera-trapping is a valuable tool for documenting natural history events, such as interactions between vertebrates in protected areas.

\section{Acknowledgements}

We thank the staff of the Barranca de Metztitlán Biosphere Reserve and CONANP for the financial support provided through the PROCER/CCER/DRCEN/04/2016 "Conservación de carnívoros silvestres en Barranca de Metztitlán" (Conservation of wild carnivores inhabiting the Barranca de Metztitlan) project. Particularly, we thank the director of the reserve, Mr. E. H. Olvera Delgadillo. We also thank the staff of the NGO Soluciones Ambientales Itzeni A. C. for their support, and Mr. G. Sánchez Martínez for his support in the field. The authors thank the two reviewers whose suggestions greatly improved and enriched our manuscript. M. E. SánchezSalazar translated the manuscript into English.

\section{Literature cited}

AnZA, J., AND F. Ziııo. 2015. Molina's Hog-nosed Skunk as prey of the Great Horned Owl: predation or opportunist scavenging? Ornithology Research 23:377-379.

Comisión Nacional de Áreas Naturales Protegidas (CONANP). 2003. Programa de Manejo Reserva de la Biosfera Barranca de Metztitlán. Comisión Nacional de Áreas Naturales Protegidas, SEMARNAT. México City, México.

Farías-González, V., and C. N. Vega-Flores. 2019. Spotted skunks (Spilogale angustifrons) photo-captured following gray foxes (Urocyon cinereoargenteus) in tropical dry forest in central Mexico. Journal of Arid Environments 160:25-31.

Fisher, K. A., ANd T. Stankowich. 2018. Antipredator strategies of striped skunks in response to cues of aerial and terrestrial predators. Animal Behaviour 143:25-34.

García, E. 1973. Modificaciones al Sistema Climático de Köppen. Instituto de Geografía. Universidad Nacional Autónoma de México. México City, México.

Instituto Nacional de Estadistica y Geografía (INEGI). 2016. Uso de suelo y vegetación, escala 1:250,000, serie VI (continuo nacional). Instituto de Estadística y Geografía. México. Downloaded at https://www.conabio.gob.mx/informacion/metadata/gis/usv250s6gw.xml? httpcache=yes \& xsl=/db/metadata/xsl/fgdc html.xsl\& indent=no. Accessed November 18, 2019.

Jenkins, K. E., P. Chanteap, D. Kanda, C. Peter, P. Cutter, T. Redford, J. L. Antony, J. Howard, and P. Leimgruber. 2011. Using relative abundance indices from camera-trapping to test wildlife conservation hypotheses-an example from Khao Yai National Park, Thailand. Tropical Conservation Science 4:113-131.

Kremer, S. R., ANd M. C. BelK. 2003. Effects of habitat disturbance on diets of great horned owl (Bubo virginianus) in a cold desert. Western North American Naturalist 63:56-62.

KopIJ, G. 2016. Diet of the great horned owl, Bubo virginianus, along a vegetation gradient in Oregon. Northwestern Naturalist 97:63-65.

Lesmeister, D. B., J. J.Millspaugh, M. E. Gompper, and T. W. Mong. 2010. Eastern spotted skunk (Spilogale putorius) survival and cause-specific mortality in the Ouachita Mountains, Arkansas. The American Midland Naturalist 164:52-60.

Mandujano, S. 2019. Analysis and trends of photo-trapping in Mexico: text mining in R. Therya 10:25-32.

Mejenes-López, S. M. A., X. Gálvez-Aguilera, G. Escalona-Segura, J. A. Vargas-Contreras, O. G. Retana-Guiascón, and G. Á. CabPaAT. 2021. First record of the coexistence of two mesocarnivores in the Yucatán Peninsula, México. Therya Notes 2:79-84. Norouzzadeh, M. S., A. Nguyen, M. Kosmala, A. Swanson, M. S. Palmer, C. Packer, and J. Clune. 2018. Automatically identi- 
fying, counting, and describing wild animals in camera-trap images with deep learning. Proceedings of the National Academy of Sciences 115:5716-5725.

Simá-Pantí, D. E., F. M. Contreras-Moreno, C. Coutiño-Cal, J. A. Zúníga-Morales, G. Méndez-Saint Martin, and R. A. ReynaHuRTADO. 2020. Morelet's crocodile predation by jaguar in the Calakmul Biosphere Reserve in southeastern México. Therya Notes 1:8-10.

Stankowich, T., P. J. Haverkamp, and T. Caro. 2014. Ecological drivers of antipredator defenses in carnivores. Evolution 68:1415e1425.

Tomazzoni, A. C., E. Pedó, and S. M. Hartz. 2004. Food habits of Great Horned Owls (Bubo virginianus) in the breeding season in Lami Biological Reserve, southern Brazil. Ornitología Neotropical 15:279-282.

Zimmerman, G., P. Stapp, and B. Van Horne. 1996. Seasonal variation in the diet of Great Horned Owls (Bubo virginianus) on shortgrass prairie. American Midland Naturalist 136:149-156.

Associated editor: José F. Moreira-Ramírez

Submitted: October 14, 2020; Reviewed: June 3, 2021.

Accepted: June 21, 2021; Published on line: July 9, 2021. 